\title{
Analisis Risiko Pelaksanaan Proyek Konstruksi Gedung Perawatan Paru dan HIV BLUD Rumah Sakit Umum Daerah Nabire
}

\author{
Mozart Riliandi ${ }^{*}$, Josefine E. Latupeirissa ${ }^{\star 2}$, Herby Calvin P. Tiyow ${ }^{* 3}$ \\ *1 Mahasiswa Program Studi Teknik Sipil, Universitas Kristen Indonesia Paulus, Makassar \\ Email mozartriliandi@gmail.com \\ *2 Dosen Program Studi Teknik Sipil, Universitas Kristen Indonesia Paulus, Makassar \\ Email Josefine ernestine@yahoo.com \\ *3 Dosen Program Studi Teknik Sipil, Universitas Kristen Indonesia Paulus, Makassar \\ Email herbycalvin@ukipaulus.ac.id
}

\begin{abstract}
ABSTRAK
Penelitian ini bertujuan, untuk menganalisis, risiko, pelaksanaan proyek, konstruksi, gedung, perawatan paru dan HIV BLUD rumah sakit umum daerah Nabire. Khususnya pada risiko pelaksanaan. Pengumpulan data berupa wawancara serta kuesioner terhadap staf diproyek. Hasil analisis 20 faktor risiko terhadap pelaksanaan proyek menyatakan bahwa kehilangan material $30 \%$, kerusakan material $32,5 \%$, kelangkaan material dipasaran $30 \%$, keterlambatan pengiriman material dari supplier $82,5 \%$, kenaikan harga material $32,5 \%$, adanya change order $70 \%$, kurang baiknya inventory control $77,5 \%$, kurangnya control dan konstruksi dalam tim 30\%, kurangnya tenaga kerja $32,5 \%$, adanya ketidakdisiplinan pekerja $35 \%$, pencurian bahan material $77,5 \%$, biaya yang tak terduga $82,5 \%$, tingginya frekuensi perubahan pekerjaan $32,5 \%$, sering terjadinya penundaan pekerjaan $32,5 \%$, pengendalian contro/ keuangan yang tak terkendali $77,5 \%$, system laporan yang kurang terkendali $87,5 \%$, perubahan kondisi perekonomian yang sering terjadi $37,5 \%$, cuaca buruk diluar kendali $80 \%$, banyaknya hasil pekerjaan yang harus diganti karena cacat atau salah $40 \%$, sering terjadinya hal-hal yang tak terduga selama pelaksanaan konstruksi $82,5 \%$. Rata-rata nilai diatas $50 \%$ dalam range berpengaruh sampai sangat berpengaruh. Dengan demikian dapat disimpulkan bahwa risiko tersebut sangat berpengaruh dalam pelaksanaan proyek konstruksi.
\end{abstract}

Kata kunci: Risiko Pelaksanaan Proyek, Skala Likert.

\section{ABSTRACT}

This study aims, to analyze, risk, project implementation, construction, building, pulmonary care and HIV BLUD general hospital Nabire area. Especially at the risk of implementation. Data collection in the form of interviews and questionnaires to staff is projected. The result of analysis of 20 risk factors for project implementation stated that material loss was $30 \%$, material damage was $32.5 \%$, material scarcity in the market $30 \%$, delays in delivery of materials from suppliers $82.5 \%$, material price increase of $32.5 \%$, change order $70 \%$, lack of inventory control $77.5 \%$, lack of control and construction in the team $30 \%$, lack of labor $32.5 \%$, indiscipline of workers $35 \%$, theft of materials $77.5 \%$, unexpected cost $82.5 \%$, high frequency of job changes $32.5 \%$, frequent job delays of $32.5 \%$, uncontrollable financial control $77.5 \%$, under-controlled reporting system $87.5 \%$, frequent changes in economic conditions $37.5 \%$, bad weather out of control $80 \%$, the number of jobs that have to be replaced due to defects or wrong $40 \%$, frequent occurrences of unexpected things during the implementation of construction $82.5 \%$. The average value above $50 \%$ in the range is influential until it is very influential. Thus it can be concluded that the risk is very influential in the implementation of construction projects.

Keywords: Project Implementation Risk, Likert Scale.

\section{PENDAHULUAN}

Proyek konstruksi merupakan suatu rangkaian kegiatan yang berkaitan dengan upaya pembangunan suatu bangunan infrastruktur. Faktorfaktor ketidakpastian dan hal-hal lain yang tidak terduga sering kali menyebabkan kegagalan pencapaian tujuan proyek pada umumnya. Proses konstruksi yang kompleks dan juga cukup lama dapat menimbulkan berbagai macam risiko yang dapat menghambat pencapaian tujuan. Dalam setiap kegiatan dapat timbul suatu risiko yang lebih besar dari yang terdeteksi atau yang sudah diperhitungkan, apabila tidak dilakukan pemantauan dan pengendalian terhadap kejadian atau keadaan tersebut. [1]

Risiko pada suatu proyek, sepatutnya muncul pada hasil yang dicapai, yang dapat berarti keseluruhan kegagalan proyek, biaya yang meningkat, dan durasi proyek yang diperpanjang di antara peristiwa yang 
Paulus Civil Engineering Journal

E- Jurnal Teknik Sipil UKI-Paulus Makassar

http://ojs.ukipaulus.ac.id/index.php/pcej
Volume 3 No.2, Juni, 2021

ISSN Online 2775-4529

ISSN Print 2775-8613 lain. Risiko seringkali diartikan sebagai faktor yang dapat menimbulkan kejadian positif dan negatif. [2]

Risiko didefinisikan sebagai kemungkinan mengalami bahaya atau penderitaan membahayakan. Secara umum, risiko dapat mengacu pada hal - hal yang sangat tidak pasti atau berbahaya. [3]

Ada bermacam - macam pengertian risiko, antara lain:

1. Risiko adalah produk dari dua faktor akibat yang diharapkan dari suatu peristiwa dan kemungkinan peristiwa itu terjadi. [4]

2. Risiko adalah suatu yang bersifat tidak pasti yang dapat menimbulkan kerugian baik pelaksana maupun pemilik proyek. [5]

3. Risiko adalah kemungkinan akan terjadinya akibat buruk atau akibat yang merugikan yang tidak bisa dijamin seratus persen bahwa akibat buruk itu setiapkali dapat dihindarkan, kecuali jika kegiatan yang mengandung risiko tidak dilakukan. [6]

4. Risiko adalah kejadian yang berpeluang mempegaruhi proyek secara negative sebagai akibat dari adanya ketidakpastian. [7]

5. Risiko adalah probabilitas suatu hasil yang berbeda dengan yang diharapkan pada setiap pekerjaan konstruksi. [8]

6. Risiko dapat diklasifikasikan menurut berbagai sudut pandang yang tergantung dari dari kebutuhan dalam penanganannya. [9]

Data yang akan dianalisis adalah data yang berasal dari responden yang merupakan para pihak yang berperan dalam proyek. Untuk menilai Jawaban Responden diberikan penilaian berdasarkan Skala Likert [10].

$\begin{array}{lll}\mathrm{SB}=\text { Sangat Berpengaruh } & \text { Bobot } & 4 \\ \mathrm{~B}=\text { Berpengaruh } & \text { Bobot } & 3 \\ \mathrm{~TB}=\text { Tidak Berpengaruh } & \text { Bobot } & 2 \\ \mathrm{STB}=\text { Sangat Tidak Berpengaruh } & \text { Bobot } & 1\end{array}$

Tujuan penelitian ini. adalah menganalisis risiko yang mungkin terjadi terhadap pelaksanaan proyek konstruksi gedung perawatan paru dan HIV BLUD rumah sakit umum daerah Nabire.

\section{METODE}

\section{A. Waktu dan Tempat Penelitian}

Penelitian, ini dilaksanakan pada, Pembangunan, Gedung, Perawatan Paru dan HIV BLUD Rumah Sakit Umum Daerah. Proyek ini terletak di Jln. R.E. Martadinata - Nabire, Kecamatan Nabire, Kabupaten Nabire sejak 2 Agustus sampai 28 Agustus 2020

\section{B. Lokasi Proyek}

Berlokasi di Jln. R.E. Marthadinata - Nabire, Kec. Nabire, Kabupaten Nabire.

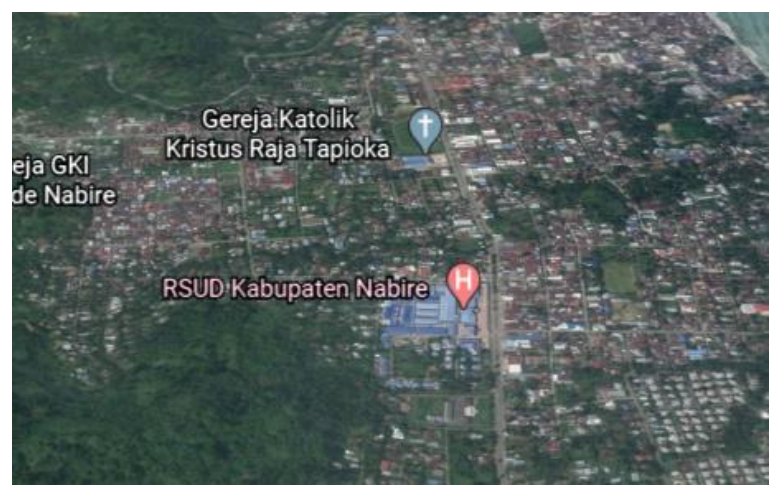

Gambar 1. Lokasi penelitian

\section{Metode Pengumpulan Data}

Dalam pengambilan informasi pada Pembagunan gedung Rumah Sakit Umun Daerah Nabire sebagai berikut:

1. Sumber Data Primer

Pengumpulan data primer pada penelitian ini dilakukan dengan menggunakan cara penyebaran kuesioner serta wawancara dengan beberapa staff diproyek. Penyebaran kuesioner dilakukan untuk mendapatkan hasil mengenai risiko yang mungkin terjadi pada proyek yang ditinjau dan seberapa besar dampaknya.

2. Sumber Data Sekunder.

Data sekunder yang digunakan adalah data Dokumen kontrak untuk mengetahui item perkerjaan.

Tabel 1. Faktor risiko pelaksanaan terhadap rumah sakit umum daerah Nabire

\begin{tabular}{cccccccc}
\hline No. & $\begin{array}{c}\text { Faktor - Faktor Risiko } \\
\text { Pelaksanaan }\end{array}$ & \multicolumn{4}{c}{ Jawaban Responden } & \multicolumn{3}{c}{ Total } \\
& RSUD Nabire & SB & B & TB & STB & Orang & $\begin{array}{c}\text { Presentase } \\
(\%)\end{array}$ \\
\hline 1. & Kehilangan material & 0 & 0 & 2 & 8 & 10 & 100 \\
2. & Kerusakan material & 0 & 0 & 3 & 7 & 10 & 100
\end{tabular}


3. Kelangkaan material di pasaran

$$
0
$$

02

8

10

100

Keterlambatan

4. pengiriman material dari

$3 \quad 7 \quad 0$

0

100

5. Kenaikan harga material

$0 \quad 0 \quad 3$

7

10

100

6. Adanya Change Order

2

0

100

\section{Control terhadap} persediaan

8. Kurangnya Control dan kordinasi dalam tim

9. Kurangnya tersedianya jumlah tenaga kerja

190

0

100

10. Adanya ketidakdisiplinan pekerja

$\begin{array}{llllll}0 & 0 & 2 & 8 & 10 & 100\end{array}$

11

Pencurian bahan material

1

12. Biaya yang tak terduga

13. Tingginya frekuensi perubahan pekerjaan

$\begin{array}{lll}3 & 7 & 0\end{array}$

7

10

100

$0 \quad 0 \quad 4$

$6 \quad 10$

100

Sering terjadinya $p$

14.

$$
\text { enundaan pekerjaan }
$$

$$
\text { ( }
$$

0

4

0

100

Pengendalian Control

15. keuangan yang tidak baik

0

$$
3
$$

6

100

Sistem laporan yang

16. kurang terkendali

Perubahan kondisi

17. perekonomian yang sering terjadi

18. Cuaca buruk diluar kendali

$1-n^{2}+0^{2}$

1

5

5

0

2

$0 \quad 0 \quad 6$

4

10

100

diganti karena cacat atau

salah

Sering terjadi hal-hal yang

20. tak terduga selama

$\begin{array}{lll}3 & 7 & 0\end{array}$

0

10

100

100

100

100

100

100

pelaksanaan konstruksi

\section{HASIL DAN PEMBAHASAN}

\section{A. Hasil}

Kehilangan material dilokasi proyek, sementara hasil kuesioner menunjukan $20 \%$ responden tidak berpengaruh dan $80 \%$ responden menjawab sangat tidak berpengaruh. Berdasarkan data tersebut maka dilakukan perhitungan berdasarkan sebagai berikut:

Total nilai 0 responden menjawab SB $=0 \times 4=0$ Total nilai 0 responden menjawab $B=0 \times 3=0$ Total nilai 2 responden menjawab TB $=2 \times 2=4$ Total nilai 8 responden menjawab STB $=8 \times 1=8$ Total nilai $=12$

Total nilai ideal untuk keseluruhan skor $=4 \times 10=40$ (apabila seluruh jawaban responden SB). Total nilai yang diperoleh dalam penelitian ini untuk pertanyaan pertama $=12$, jadi berdasarkan data itu maka tingkat persetujuan terhadap kelalaian dalam bekerja 
Paulus Civil Engineering Journal

E- Jurnal Teknik Sipil UKI-Paulus Makassar

http://ojs.ukipaulus.ac.id/index.php/pcej
Volume 3 No.2, Juni, 2021

ISSN Online 2775-4529

ISSN Print 2775-8613 diperoleh rata-rata jawaban terletak pada daerah sangat tidak berpengaruh yaitu: $(12: 40) \times 100 \%=$ $30 \%$

Kerusakan Material, sementara hasil kuesioner menunjukan $30 \%$ responden tidak berpengaruh dan $70 \%$ responden menjawab sangat tidak berpengaruh. Berdasarkan data tersebut maka dilakukan perhitungan sebagai berikut:

Total nilai 0 responden menjawab SB $\quad=0 \times 4=0$ Total nilai 0 responden menjawab $B=0 \times 3=0$ Total nilai 3 responden menjawab TB $=3 \times 2=6$ Total nilai 7 responden menjawab STB $=7 \times 1=7$ Total nilai $=13$

Total nilai ideal untuk keseluruhan item $=4 \times 10=40$ (apabila seluruh jawaban responden SB). Total nilai yang diperoleh dalam penelitian ini untuk pertanyaan kedua $=13$, jadi berdasarkan data itu maka tingkat persetujuan terhadap kelalaian dalam bekerja diperoleh rata-rata jawaban terletak pada daerah sangat tidak berpengaruh yaitu: $(13: 40) \times 100 \%=$ $32,5 \%$

Kelangkaan material di pasaran, sementara hasil kuesioner menunjukan 20\% responden tidak berpengaruh dan $80 \%$ responden menjawab sangat tidak berpengaruh. Berdasarkan data tersebut maka dilakukan perhitungan berdasarkan sebagai berikut:

Total nilai 0 responden menjawab $\mathrm{SB}=0 \times 4=0$ Total nilai 0 responden menjawab $B=0 \times 3=0$ Total nilai 2 responden menjawab TB $=2 \times 2=4$ Total nilai 8 responden menjawab STB $=8 \times 1=8$ Total nilai $=12$

Total nilai ideal untuk keseluruhan item $=4 \times 10=40$ (apabila seluruh jawaban responden SB). Total nilai yang diperoleh dalam penelitian ini untuk pertanyaan ketiga $=12$, jadi berdasarkan data itu maka tingkat persetujuan terhadap kelalaian dalam bekerja diperoleh rata-rata jawaban terletak pada daerah sangat tidak berpengaruh yaitu: $(12: 40) \times 100 \%=$ $30 \%$

Keterlambatan pengiriman material dari supplier, sementara hasil kuesioner menunjukan 30\% responden tidak berpengaruh dan $70 \%$ responden menjawab sangat tidak berpengaruh. Berdasarkan data tersebut maka dilakukan perhitungan berdasarkan sebagai berikut:

Total nilai 0 responden menjawab SB Total nilai 0 responden menjawab $B$ Total nilai 2 responden menjawab TB
$=3 \times 4=12$ $=7 \times 3=21$ $=0 \times 2=0$
Total nilai 8 responden menjawab STB $=0 \times 1=0$ Total nilai $=33$

Total nilai ideal untuk keseluruhan skor $=4 \times 10=40$ (apabila seluruh jawaban responden SB). Total nilai yang diperoleh dalam penelitian ini untuk pertanyaan keempat $=33$, jadi berdasarkan data itu maka tingkat persetujuan terhadap kelalaian dalam bekerja diperoleh rata-rata jawaban terletak pada daerah sangat tidak berpengaruh yaitu: $(33: 40) \times 100 \%=$ $82,5 \%$

Kenaikan harga material, sementara hasil kuesioner menunjukan $30 \%$ responden tidak berpengaruh dan $70 \%$ responden menjawab sangat tidak berpengaruh. Berdasarkan data tersebut maka dilakukan perhitungan berdasarkan sebagai berikut:

Total nilai 0 responden menjawab SB $=0 \times 4=0$ Total nilai 0 responden menjawab $B=0 \times 3=0$ Total nilai 3 responden menjawab TB $=3 \times 2=6$ Total nilai 7 responden menjawab STB $=7 \times 1=7$ Total nilai $=13$

Total nilai ideal untuk keseluruhan skor $=4 \times 10=40$ (apabila seluruh jawaban responden SB). Total nilai yang diperoleh dalam penelitian ini untuk pertanyaan kelima $=13$, jadi berdasarkan data itu maka tingkat persetujuan terhadap kelalaian dalam bekerja diperoleh rata-rata jawaban terletak pada daerah sangat tidak berpengaruh yaitu: $(13: 40) \times 100 \%=$ $32,5 \%$

Adanya Change order, sementara hasil kuesioner menunjukan $20 \%$ responden tidak berpengaruh dan $80 \%$ responden menjawab sangat tidak berpengaruh. Berdasarkan data tersebut maka dilakukan perhitungan berdasarkan sebagai berikut:

Total nilai 2 responden menjawab SB $=2 \times 4=8$ Total nilai 8 responden menjawab $B \quad=8 \times 3=24$ Total nilai 0 responden menjawab TB $=0 \times 2=0$ Total nilai 0 responden menjawab STB $=0 \times 1=0$ Total nilai $=32$

Total nilai ideal untuk keseluruhan skor $=4 \times 10=40$ (apabila seluruh jawaban responden SB). Total nilai yang diperoleh dalam penelitian ini untuk pertanyaan keenam $=32$, jadi berdasarkan data itu maka tingkat persetujuan terhadap kelalaian dalam bekerja diperoleh rata-rata jawaban terletak pada daerah sangat tidak berpengaruh yaitu: $(32: 40) \times 100 \%=$ $80 \%$

Kurang baiknya Inventory Control terhadap persediaan, sementara hasil kuesioner menunjukan 
Paulus Civil Engineering Journal

E- Jurnal Teknik Sipil UKI-Paulus Makassar

http://ojs.ukipaulus.ac.id/index.php/pcej
Volume 3 No.2, Juni, 2021

ISSN Online 2775-4529

ISSN Print 2775-8613
$10 \%$ responden tidak berpengaruh dan $90 \%$ responden menjawab sangat tidak berpengaruh. Berdasarkan data tersebut maka dilakukan perhitungan berdasarkan sebagai berikut:

Total nilai 1 responden menjawab SB

Total nilai 9 responden menjawab $B$

$=1 \times 4=8$

Total nilai 0 responden menjawab TB

$=9 \times 3=27$

Total nilai 0 responden menjawab STB $=0 \times 1=0$

Total nilai

$=31$

Total nilai ideal untuk keseluruhan skor $=4 \times 10=40$ (apabila seluruh jawaban responden SB). Total nilai yang diperoleh dalam penelitian ini untuk pertanyaan ketujuh $=31$, jadi berdasarkan data itu maka tingkat persetujuan terhadap kelalaian dalam bekerja diperoleh rata-rata jawaban terletak pada daerah sangat tidak berpengaruh yaitu: $(31: 40) \times 100 \%=$ $77,5 \%$

Kurangnya Control dan kordinasi dalam tim, sementara hasil kuesioner menunjukan 30\% responden tidak berpengaruh dan $70 \%$ responden menjawab sangat tidak berpengaruh. Berdasarkan data tersebut maka dilakukan perhitungan berdasarkan sebagai berikut:

Total nilai 0 responden menjawab SB $=0 \times 4=0$ Total nilai 0 responden menjawab $B=0 \times 3=0$ Total nilai 2 responden menjawab TB $=2 \times 2=4$ $\begin{array}{ll}\text { Total nilai } 8 \text { responden menjawab STB } & =8 \times 1=8 \\ \text { Total nilai } & =12\end{array}$

Total nilai ideal untuk keseluruhan skor $=4 \times 10=40$ (apabila seluruh jawaban responden SB). Total nilai yang diperoleh dalam penelitian ini untuk pertanyaan kedelapan $=12$, jadi berdasarkan data itu maka tingkat persetujuan terhadap kelalaian dalam bekerja diperoleh rata-rata jawaban terletak pada daerah sangat tidak berpengaruh yaitu: $(12: 40) \mathrm{x}$ $100 \%=30 \%$

Kurang tersedianya jumlah tenaga kerja, sementara hasil kuesioner menunjukan 30\% responden tidak berpengaruh dan $70 \%$ responden menjawab sangat tidak berpengaruh. Berdasarkan data tersebut maka dilakukan perhitungan berdasarkan sebagai berikut:

Total nilai 0 responden menjawab SB $=0 \times 4=0$ Total nilai 0 responden menjawab $B=0 \times 3=0$ Total nilai 3 responden menjawab TB $=3 \times 2=6$ Total nilai 7 responden menjawab STB $\quad=7 \times 1=7$ Total nilai $=13$

Total nilai ideal untuk keseluruhan skor $=4 \times 10=40$ (apabila seluruh jawaban responden SB). Total nilai yang diperoleh dalam penelitian ini untuk pertanyaan kesembilan $=13$, jadi berdasarkan data itu maka tingkat persetujuan terhadap kelalaian dalam bekerja diperoleh rata-rata jawaban terletak pada daerah sangat tidak berpengaruh yaitu: (13:40) $x$ $100 \%=32,5 \%$

Adanya ketidakdisiplinan pekerja, sementara hasil kuesioner menunjukan 40\% responden tidak berpengaruh dan $60 \%$ responden menjawab sangat tidak berpengaruh. Berdasarkan data tersebut maka dilakukan perhitungan berdasarkan sebagai berikut:

Total nilai 0 responden menjawab SB $=0 \times 4=0$ Total nilai 0 responden menjawab $B=0 \times 3=0$ Total nilai 4 responden menjawab TB $=4 \times 2=8$ Total nilai 6 responden menjawab STB $=6 \times 1=6$ Total nilai $=14$

Total nilai ideal untuk keseluruhan skor $=4 \times 10=40$ (apabila seluruh jawaban responden SB). Total nilai yang diperoleh dalam penelitian ini untuk pertanyaan kesepuluh $=14$, jadi berdasarkan data itu maka tingkat persetujuan terhadap kelalaian dalam bekerja diperoleh rata-rata jawaban terletak pada daerah sangat tidak berpengaruh yaitu: (14:40) $x$ $100 \%=35 \%$

Pencurian bahan material, sementara hasil kuesioner menunjukan $10 \%$ responden tidak berpengaruh dan $90 \%$ responden menjawab sangat tidak berpengaruh. Berdasarkan data tersebut maka dilakukan perhitungan berdasarkan sebagai berikut:

Total nilai 1 responden menjawab SB $=1 \times 4=4$ Total nilai 9 responden menjawab B $=9 \times 3=27$ Total nilai 0 responden menjawab TB $=0 \times 2=0$ Total nilai 0 responden menjawab STB $=0 \times 1=0$ Total nilai $=31$

Total nilai ideal untuk keseluruhan skor $=4 \times 10=40$ (apabila seluruh jawaban responden SB). Total nilai yang diperoleh dalam penelitian ini untuk pertanyaan kesebelas $=31$, jadi berdasarkan data itu maka tingkat persetujuan terhadap kelalaian dalam bekerja diperoleh rata-rata jawaban terletak pada daerah sangat tidak berpengaruh yaitu: (31:40) $x$ $100 \%=77,5 \%$

Biaya yang tak terduga, sementara hasil kuesioner menunjukan $30 \%$ responden tidak berpengaruh dan $70 \%$ responden menjawab sangat tidak berpengaruh. Berdasarkan data tersebut maka dilakukan perhitungan berdasarkan sebagai berikut:

Total nilai 3 responden menjawab SB $\quad=3 \times 4=12$ 
Paulus Civil Engineering Journal

E- Jurnal Teknik Sipil UKI-Paulus Makassar

http://ojs.ukipaulus.ac.id/index.php/pcej
Volume 3 No.2, Juni, 2021

ISSN Online 2775-4529

ISSN Print 2775-8613
Total nilai 7 responden menjawab $B \quad=7 \times 3=21$

Total nilai 0 responden menjawab TB $\quad=0 \times 2=0$

Total nilai 0 responden menjawab STB $=0 \times 1=0$

Total nilai

$=33$

Total nilai ideal untuk keseluruhan skor $=4 \times 10=40$ (apabila seluruh jawaban responden SB). Total nilai yang diperoleh dalam penelitian ini untuk pertanyaan keduabelas $=33$, jadi berdasarkan data itu maka tingkat persetujuan terhadap kelalaian dalam bekerja diperoleh rata-rata jawaban terletak pada daerah sangat tidak berpengaruh yaitu: (33:40) $x$ $100 \%=82,5 \%$

Tingginya frekuensi perubahan pekerjaan, sementara hasil kuesioner menunjukan 40\% responden tidak berpengaruh dan $60 \%$ responden menjawab sangat tidak berpengaruh. Berdasarkan data tersebut maka dilakukan perhitungan berdasarkan sebagai berikut:

Total nilai 0 responden menjawab SB $=0 \times 4=0$ Total nilai 0 responden menjawab $B=0 \times 3=0$ Total nilai 4 responden menjawab TB $=4 \times 2=8$ Total nilai 6 responden menjawab STB $=6 \times 1=6$ Total nilai $=14$

Total nilai ideal untuk keseluruhan skor $=4 \times 10=40$ (apabila seluruh jawaban responden SB). Total nilai yang diperoleh dalam penelitian ini untuk pertanyaan ketigabelas $=14$, jadi berdasarkan data itu maka tingkat persetujuan terhadap kelalaian dalam bekerja diperoleh rata-rata jawaban terletak pada daerah sangat tidak berpengaruh yaitu: (14:40) $x$ $100 \%=35 \%$

Sering terjadinya penundaan pekerjaan, sementara hasil kuesioner menunjukan 30\% responden tidak berpengaruh dan $70 \%$ responden menjawab sangat tidak berpengaruh. Berdasarkan data tersebut maka dilakukan perhitungan berdasarkan sebagai berikut:

Total nilai 0 responden menjawab SB $=0 \times 4=0$ Total nilai 0 responden menjawab $B=0 \times 3=0$ Total nilai 3 responden menjawab TB $=3 \times 2=8$ Total nilai 7 responden menjawab STB $=7 \times 1=6$ Total nilai $=13$

Total nilai ideal untuk keseluruhan skor $=4 \times 10=40$ (apabila seluruh jawaban responden SB). Total nilai yang diperoleh dalam penelitian ini untuk pertanyaan keempatbelas $=13$, jadi berdasarkan data itu maka tingkat persetujuan terhadap kelalaian dalam bekerja diperoleh rata-rata jawaban terletak pada daerah sangat tidak berpengaruh yaitu: (13:40) $x$ $100 \%=32,5 \%$

Pengendalian Control keuangan yang tidak baik, sementara hasil kuesioner menunjukan 10\% responden tidak berpengaruh dan $90 \%$ responden menjawab sangat tidak berpengaruh. Berdasarkan data tersebut maka dilakukan perhitungan berdasarkan sebagai berikut:

Total nilai 1 responden menjawab SB $=1 \times 4=4$ Total nilai 9 responden menjawab $B \quad=9 \times 3=27$ Total nilai 0 responden menjawab TB $=0 \times 2=0$ Total nilai 0 responden menjawab STB $=0 \times 1=0$ Total nilai $=31$

Total nilai ideal untuk keseluruhan skor $=4 \times 10=40$ (apabila seluruh jawaban responden SB). Total nilai yang diperoleh dalam penelitian ini untuk pertanyaan kelima belas $=31$, jadi berdasarkan data itu maka tingkat persetujuan terhadap kelalaian dalam bekerja diperoleh rata-rata jawaban terletak pada daerah sangat tidak berpengaruh yaitu: (31:40) $x$ $100 \%=77,5 \%$

Sistem laporan yang kurang terkendali, sementara hasil kuesioner menunjukan $50 \%$ responden tidak berpengaruh dan $50 \%$ responden menjawab sangat tidak berpengaruh. Berdasarkan data tersebut maka dilakukan perhitungan berdasarkan sebagai berikut:

Total nilai 5 responden menjawab SB $=5 \times 4=20$ Total nilai 5 responden menjawab $B \quad=5 \times 3=15$ Total nilai 0 responden menjawab TB $=0 \times 2=0$ Total nilai 0 responden menjawab STB $=0 \times 1=0$ Total nilai $=35$

Total nilai ideal untuk keseluruhan skor $=4 \times 10=40$ (apabila seluruh jawaban responden SB). Total nilai yang diperoleh dalam penelitian ini untuk pertanyaan keenambelas $=35$, jadi berdasarkan data itu maka tingkat persetujuan terhadap kelalaian dalam bekerja diperoleh rata-rata jawaban terletak pada daerah sangat tidak berpengaruh yaitu: $(35: 40) \mathrm{x}$ $100 \%=87,5 \%$

Perubahan kondisi perekonomian yang sering terjadi, sementara hasil kuesioner menunjukan $50 \%$ responden tidak berpengaruh dan $50 \%$ responden menjawab sangat tidak berpengaruh. Berdasarkan data tersebut maka dilakukan perhitungan berdasarkan sebagai berikut:

Total nilai 0 responden menjawab SB $=0 \times 4=0$ Total nilai 0 responden menjawab $B=0 \times 3=0$ Total nilai 5 responden menjawab TB $\quad=5 \times 2=10$ 
Paulus Civil Engineering Journal

E- Jurnal Teknik Sipil UKI-Paulus Makassar

http://ojs.ukipaulus.ac.id/index.php/pcej
Volume 3 No.2, Juni, 2021

ISSN Online 2775-4529

ISSN Print 2775-8613
Total nilai 5 responden menjawab STB $=5 \times 1=5$ Total nilai $=15$

Total nilai ideal untuk keseluruhan skor $=4 \times 10=40$ (apabila seluruh jawaban responden SB). Total nilai yang diperoleh dalam penelitian ini untuk pertanyaan ketujuhbelas $=15$, jadi berdasarkan data itu maka tingkat persetujuan terhadap kelalaian dalam bekerja diperoleh rata-rata jawaban terletak pada daerah sangat tidak berpengaruh yaitu: $(15: 40) \mathrm{x}$ $100 \%=37,5 \%$

Cuaca buruk diluar kendali, sementara hasil kuesioner menunjukan 20\% responden tidak berpengaruh dan $80 \%$ responden menjawab sangat tidak berpengaruh. Berdasarkan data tersebut maka dilakukan perhitungan berdasarkan sebagai berikut:

Total nilai 2 responden menjawab SB $=2 \times 4=8$ Total nilai 8 responden menjawab $B \quad=8 \times 3=24$ Total nilai 0 responden menjawab TB $=0 \times 2=0$ Total nilai 0 responden menjawab $\mathrm{STB}=0 \times 1=0$ Total nilai $=32$

Total nilai ideal untuk keseluruhan skor $=4 \times 10=40$ (apabila seluruh jawaban responden SB). Total nilai yang diperoleh dalam penelitian ini untuk pertanyaan kedelapanbelas $=32$, jadi berdasarkan data itu maka tingkat persetujuan terhadap kelalaian dalam bekerja diperoleh rata-rata jawaban terletak pada daerah sangat tidak berpengaruh yaitu: $(32: 40) x$ $100 \%=80 \%$

Banyaknya hasil pekerjaan yang harus diganti karena cacat atau salah, sementara hasil kuesioner menunjukan $60 \%$ responden tidak berpengaruh dan $40 \%$ responden menjawab sangat tidak berpengaruh. Berdasarkan data tersebut maka dilakukan perhitungan berdasarkan sebagai berikut:

Total nilai 0 responden menjawab SB $=0 \times 4=0$ Total nilai 0 responden menjawab $B=0 \times 3=0$ Total nilai 6 responden menjawab TB $=6 \times 2=12$ Total nilai 6 responden menjawab STB $=4 \times 1=4$ Total nilai $=16$

Total nilai ideal untuk keseluruhan skor $=4 \times 10=40$ (apabila seluruh jawaban responden SB). Total nilai yang diperoleh dalam penelitian ini untuk pertanyaan kesembilanbelas $=16$, jadi berdasarkan data itu maka tingkat persetujuan terhadap kelalaian dalam bekerja diperoleh rata-rata jawaban terletak pada daerah sangat tidak berpengaruh yaitu: $(16: 40) \mathrm{x}$ $100 \%=40 \%$
Sering terjadi hal-hal yang tak terduga selama pelaksanaan konstruksi, sementara hasil kuesioner menunjukan $40 \%$ responden tidak berpengaruh dan $60 \%$ responden menjawab sangat tidak berpengaruh. Berdasarkan data tersebut maka dilakukan perhitungan berdasarkan sebagai berikut:

Total nilai 7 responden menjawab SB $=3 \times 4=12$ Total nilai 3 responden menjawab $B=7 \times 3=21$ Total nilai 0 responden menjawab TB $=0 \times 2=0$ Total nilai 0 responden menjawab STB $=0 \times 1=0$ Total nilai $=33$

Total nilai ideal untuk keseluruhan skor $=4 \times 10=40$ (apabila seluruh jawaban responden SB). Total nilai yang diperoleh dalam penelitian ini untuk pertanyaan kesepuluh $=33$, jadi berdasarkan data itu maka tingkat persetujuan terhadap kelalaian dalam bekerja diperoleh rata-rata jawaban terletak pada daerah sangat tidak berpengaruh yaitu: $(33: 40) \times$ $100 \%=82,5 \%$

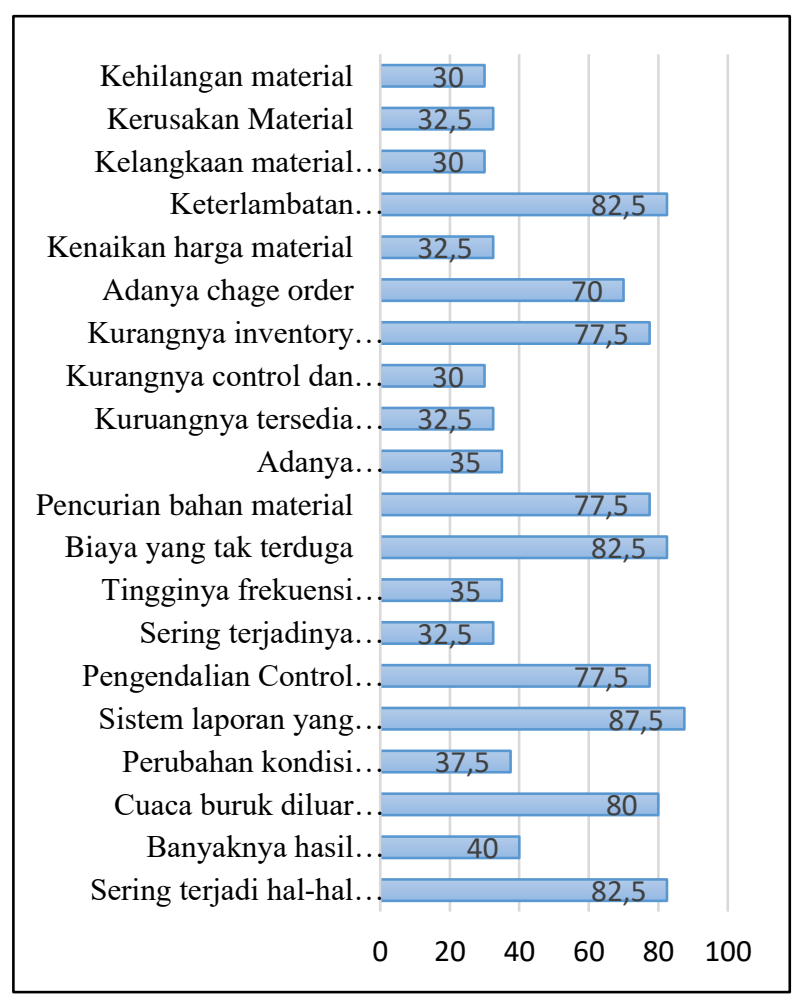

Gambar 2. Diagram persentase faktor - faktor risiko pelaksanaan

\section{KESIMPULAN}

Hasil penelitian yang telah dilakukan melalui identifikasi survei responden untuk mengetahui faktor risiko yang kemungkinan terjadi pada pelaksanaan proyek bangunan gedung di rumah 
Paulus Civil Engineering Journal

E- Jurnal Teknik Sipil UKI-Paulus Makassar

http://ojs.ukipaulus.ac.id/index.php/pcej
Volume 3 No.2, Juni, 2021

ISSN Online 2775-4529

ISSN Print 2775-8613 sakit umum daerah Nabire, maka dapat disimpulkan bahwa yang sangat berpengaruh dalam pelaksanaan proyek konstruksi ialah: Keterlambatan pengiriman material dari supplier $82,5 \%$, Adanya change order $70 \%$, Biaya yang tak terduga $82,5 \%$, Sistem laporan yang kurang terkendali $87,5 \%$, Pengendalian control keuangan yang tidak baik $77,5 \%$, Kurang baiknya inventory control terhadap persediaan $77,5 \%$, Pencurian bahan material $77,5 \%$, Cuaca buruk di luar kendali $80 \%$, dan Sering terjadinya hal hal yang tidak terduga selama pelaksanaan konstruksi $82,5 \%$.

\section{DAFTAR PUSTAKA}

[1] Benhart E. Situmorang, Tisano Tj. Arsjad, Jermias Tjakra, 2018, "Analisis Risiko Pelaksanaan Pembagunan Proyek Konstruksi Bagunan Gedung," Tekno, Volume.16, Nomor. 69, HIm. 31-35

[2] Dewi, A. I., dan Nurcahyo, C. B, 2013, "Analisa Risiko Pada Proyek Pembangunan Underpass Di Simpang Dewa Ruci Kuta Bali". Jurnal Teknik ITS, Volume. 2, Nomor. 2, HIm. C72C77, doi: 10.12962/j23373539.v2i2.4162

[3] Wena M, 2015, "Manajemen Risiko Dalam Proyek Konstruksi", Jurnal Bangunan, Volume 20 Nomor. 1. HIm. 1-12.

[4] Hawari K. 2009, "Identifikasi Risiko Proyek Pada Tahap Konstruksi Bangunan Bertingkat 420 Lantai Di Jabotabek Dari Sudut Pandang Kontraktor", Skripsi, Fakultas Teknik. Universitas Indonesia. Depok.
[5] Supriono L. 2014, "Faktor-Faktor Resiko Keterlambatan Pembangunan Proyek Infrastruktur Perdesaan Berdasarkan Waktu Perencanaan Proyek PPIP Kec. Bringin Kab. Ngawi”, Jurnal Teknik Sipil, Volume.7, Nomor.1, HIm. 63-73

[6] Rifai W. 2018, "Analisis Risiko Keterlambatan Pelaksanaan Konstruksi Proyek Spazio Tower 2 Surabaya", Doctoral dissertation, Institut Teknologi Sepuluh Nopember.

[7] Tjakra J. dan Sangari F, 2011, "Analisis Resiko Pada Proyek Konstruksi Perumahan di Kota Manado", Jurnal IImiah Media Engineering, Volume. 1, Nomor. 1. HIm. 29-37

[8] Ismiyati, Sanggawuri R. dan Handajani M, 2019, "Penerapan Manajemen Resiko pada Pembangunan Proyek Perpanjangan Dermaga log Pelabuhan DalamTanjung Emas Semarang", Media Komunikasi Teknik Sipil, Volume. 25, Nomor. 2, HIm. 209-220. doi: mkts.v25i2.19467

[9] Mastura L. 2011. "Manajemen Risiko Dalam Proyek Konstruksi", Jurnal SMARTek, Volume. 9, Nomor. 1, HIm. 39-46.

[10] Tambunan R. S., Sopacua, H. A., dan Latupeirissa, J. E. 2020, "Peristiwa Ketidakpastian Pada Pelaksanaan Tol Layang AP Pettarani Seksi III Kota Makassar", Paulus Civil Engineering Journal, Volume. 2, Nomor. 1, HIm. 46-52 